\title{
Total Replacement of Fish Meal With processed Poultry Offal Meal (P-POM) Enhances the Growth Performance and Feed Utilization in Snakehead, Channa Striata (Bloch, 1793)
} Juveniles

\author{
Mustapar NN ${ }^{1}$, Abdul Hamid NK${ }^{1}$, Hashim R $^{2}$ and Mohd Nor SA ${ }^{1,3}$ \\ ${ }^{1}$ School of Biological Sciences, Universiti Sains Malaysia, Malaysia \\ ${ }^{2}$ Faculty of Science and Technology, Universiti Sains Islam Malaysia, Malaysia \\ ${ }^{3}$ Institute of Marine Biotechnology, Universiti Malaysia Terengganu, Malaysia
}

\section{Research Article \\ Volume 2 Issue 3}

Received Date: April 24, 2018

Published Date: May 09, 2018

*Corresponding author: Nurul Nadiah Mustapar, School of Biological Science, Universiti Sains Malaysia, 11800 Penang, Malaysia, Tel: +6019-5610626; Email: nurulnadya_90@yahoo.com

\section{Abstract}

This study was conducted to evaluate the replacement of fishmeal (FM) with processed poultry offal meal (P-POM) on growth performance and diet digestibility in snakehead, Channa striata juveniles. Fish (mean initial weight $(13.23 \pm 0.06)$ were reared in 15 black 500l-fiberglass tanks and fed with five isonitrogenous (40\% crude protein) and isocaloric (18.90kJ/g gross energy) diets, respectively, in triplicates. The control diet (D1) was formulated to contain 40\% FM protein and the remaining diets replaced FM protein with P-POM in increasing order, 25\% (D2), 50\% (D3), 75\% (D4) and 100\% (D5). Fish were fed the assigned diet twice daily until apparent satiation for 12 weeks. Fish fed D4 (75\% replacement) resulted in significantly higher growth performance and feed utilization. The HSI values increased significantly from $50 \%$ to $100 \%$ replacement levels while VSI value was significantly highest at $75 \%$ replacement level. Lipase activities were significantly highest for the $25 \%$ up to $75 \%$ replacement levels but only $75 \%$ replacement level resulted in significantly highest protease activity. The apparent dry matter digestibility increased significantly with increasing levels of P-POM up to 75\% replacement levels while no significant differences was observed in the apparent protein digestibility between treatments accept the fish fed $100 \%$ replacement level. Both apparent dry matter and protein digestibilities were significantly lower at $100 \%$ replacement levels. The results from this feeding trial indicate that the P-POM protein can replace up to 75\% FM protein diets for snakehead fingerlings without affecting the survival, growth performance and feed utilization.

Keyword: Fish Meal; Lab Processed Poultry Offal Meal; Snakehead; Growth 


\section{International Journal of Oceanography \& Aquaculture}

\section{Introduction}

Channa striata, or snakehead, is carnivorous freshwater fish which inhabits all types of freshwater water bodies from small ditches to rice fields, rivers, ponds and lakes across tropical and subtropical Asian countries [1,2]. It belongs to the Channidae family and known as a common freshwater species that is a popular food source among South East Asia $[3,4]$ due to its firm, white and boneless tasty flesh and easy to culture making it suitable for aquaculture [3]. Over the last decade, the total global aquaculture production for $C$. Striata has been increasing and by 2014 the total production of this species reached 17 thousand tonnes [5]. Its fast growth rate, air-breathing ability, hardiness, high tolerance to adverse environmental conditions and benefits as a therapeutic agent have led to the rising aquaculture of this species to meet the demands of the pharmaceutical and food fish industries [6,3].

However, the culture of carnivorous fish species requires additional attention because of the higher demand for animal protein especially fish meal. Fish meal is the main protein source used globally especially for carnivorous fish species but its high cost, fluctuation in supply and shortage of quantity [7], has necessitated the search for alternative protein sources as a replacement to fish meal. In addition, due to longer culture periods of this species, 7 to 9 months to reach marketable size, the capital investment for the intensive culture is also high. Therefore, there is an urgent need to identify other more cost effective protein sources to minimize or lessen the use of fish meal in its diets. The candidate protein source must be cheap preferably a by-product from an animal processing industry, good in quality and readily available as a substitute for fish meal in the diets. To date success on the use of animal protein as a replacement of fish meal in diets of warm water fish species have been reported with respect to their abundance, low cost, higher protein content and superior indispensable amino acid profile [8]. Among the many animal proteins screened and tested, poultry offal meal is one of the promising alternative protein source that can be used to substitute fish meal in aqua feed $[9,10]$.

In 2014, the total global production of poultry meat reached 109 thousand metric tonnes and it is expected to rise in the near future [11]; this growth is accompanied by the waste by product from the processing of poultry industry which has detrimental effects to the environment. Improper disposal of poultry by product and carcasses contribute to the water quality problem especially to the area surrounding the processing plants and also in areas prone to flooding or where there is a shallow water bodies [12]. Poultry offals released to the environment are vectors for insects, pests, bacteria and viruses, which may result in water contamination and air pollution if they are not properly managed [13]. Thus, processing poultry offals into aquaculture feed is a good way to reduce the environmental problems caused by the poultry processing industry. The nutrient content of poultry offal meal can vary depending on the source, quality and processing technique [14]. High quality poultry offal meal has similar nutrient profile, amino acid and fatty acid profile and high palatability properties to fish meal and they are widely used in aquaculture industry [15,16]. Therefore, the main objective of the present study was to evaluate the replacement of fish meal with a lab processed poultry offal meal to evaluate the feasibility of P- POM as a protein source for snakehead, C. Striata juveniles.

\section{Materials and Methods}

\section{Ingredients and Experimental Diets}

Five experimental diets were formulated to contain $40 \%$ protein and $12 \%$ lipid, at four different inclusion levels of protein from poultry offal meal: $25 \%$ (D2), $50 \%$ (D3), 75\% (D4) and 100\% (D5). The control diet (D1) contained only FM protein. The proximate composition of ingredients and experimental diets [17] was presented in Table 1 and the amino acid analysis was performed on a high pressure liquid chromatography (HPLC) was presented in Table 2. Fish meal and processed poultry offal meal (P-POM) were used as protein sources in this study. Fresh poultry offal were purchased from the local market, cleaned to remove the internal contents and visceral fat, cooked, dried and ground. The ground poultry offal meal was then defatted using hexane to reduce the lipid level prior to diet preparation. The amino acid profile of the FM and P-POM is showed in Table 2. Fish oil and poultry fat were used to balance the lipid level in the diets. The diets were prepared by mixing all the ingredients with a mixer (Tyrone model, TR202; L.J Stuart \& Company, Sydney, Australia) and 0.5\% chromium oxide was added as an inert marker for digestibility determination. The moist dough was passed through a meat grinder (Model MH237, Miao Hsien Ltd., Taichung, Taiwan) to form a strand like string shaped pellet which were then oven dried at $60 \mathrm{oC}$ overnight. The pellets were stored at $-20^{\circ} \mathrm{C}$ until used for the feeding trial. 


\section{International Journal of Oceanography \& Aquaculture}

\begin{tabular}{|c|c|c|c|c|c|}
\hline \multirow{2}{*}{ Ingredients (g/100g) } & \multicolumn{5}{|c|}{ Experimental Diets } \\
\hline & D1 & D2 & D3 & D4 & D5 \\
\hline Fish Meal $^{1}$ & 60.22 & 37.64 & 30.11 & 22.58 & 0 \\
\hline Defatted Poultry Offal Meal² & 0 & 22.24 & 29.66 & 37.07 & 59.31 \\
\hline Corn Starch & 26.9 & 24.6 & 23.9 & 23.1 & 20.8 \\
\hline Fish Oil & 0.28 & 2.43 & 3.14 & 3.86 & 6 \\
\hline Poultry Fat ${ }^{3}$ & 6 & 3.95 & 3.26 & 2.58 & 0.53 \\
\hline Carboxymethyl cellulose & 2 & 2 & 2 & 2 & 2 \\
\hline Cellulose & 6.44 & 8.32 & 8.88 & 9.54 & 11.43 \\
\hline Vitamin $\mathrm{Mix}^{4}$ & 2 & 2 & 2 & 2 & 2 \\
\hline Mineral Mix 5 & 2 & 2 & 2 & 2 & 2 \\
\hline $\mathrm{Cr}_{2} \mathrm{O}_{3}{ }^{6}$ & 0.5 & 0.5 & 0.5 & 0.5 & 0.5 \\
\hline \multicolumn{6}{|c|}{ Proximate composition (\%dry matter basis) } \\
\hline Crude protein & 40.91 & 40.79 & 40.67 & 40.59 & 40.71 \\
\hline Crude lipid & 11.72 & 11.5 & 11.39 & 11.52 & 11.03 \\
\hline Ash & 6.55 & 4.88 & 4.32 & 3.77 & 2.1 \\
\hline Fibre & 6.55 & 7.32 & 7.88 & 8.24 & 8.43 \\
\hline Moisture & 5.94 & 4.31 & 4.31 & 4.3 & 4.65 \\
\hline $\mathrm{NFE}^{7}$ & 28.33 & 31.2 & 31.43 & 31.58 & 33.08 \\
\hline GE(MJkg-1) ${ }^{8}$ & 18.4 & 18.6 & 18.3 & 18.2 & 18.2 \\
\hline
\end{tabular}

Table 1: Proximate composition of experimental diets.

${ }^{1}$ Danish Fishmeal ( $\left.\mathrm{g} \mathrm{kg}^{-1} \mathrm{DM}\right)$, CP: 740, CL: 102

2Defatted Poultry Offal Meal (g kg-1 DM), Al Ikhwan Processing Sdn. Bhd. Penang, Malaysia

${ }^{3}$ Poultry fat, Al Ikhwan Processing Sdn. Bhd. Penang, Malaysia

${ }^{4}$ Vitamin premix (Rovimix 6288; F.Hoffman La-Roche Ltd, Basel, Switzerland), containing (per kg,dry weight): Vitamin A, 50 million I.U.; Vitamin D3, 10 million I.U.; Vitamin E, 130 g; Vitamin B1, 10 g; Vitamin B2, 25 g; Vitamin B6, 16 g; Vitamin B12, $100 \mathrm{mg}$; biotin,500 mg; panthothenic acid, 56 g; folic acid, 8 g; niacin, 200 g; anti-cake20 g; antioxidant, $200 \mathrm{mg}$; Vitamin K3, $10 \mathrm{~g}$; and Vitamin c, $35 \mathrm{~g}$

${ }^{5}$ Mineral premix g kg-1; calcium phosphate (monobasic), $397.5 \mathrm{~g}$; calcium lactate, $327 \mathrm{~g}$; ferrous sulphate, $25 \mathrm{~g}$; magnesium sulphate, $137 \mathrm{~g}$; potassium chloride, $50 \mathrm{~g}$; sodium chloride, $60 \mathrm{~g}$; potassium iodide, $150 \mathrm{mg}$; copper sulphate, $780 \mathrm{mg}$; manganese oxide, $800 \mathrm{mg}$; cobalt carbonate, $100 \mathrm{mg}$; zinc oxide, $1.5 \mathrm{~g}$; and sodium selenite, $200 \mathrm{mg}$.

${ }^{6}$ Chromium oxide as an inert marker for digestibility test

${ }^{7}$ Nitrogen free extract: 100 - (protein+ lipid +ash+ fiber)

${ }^{8}$ Gross Energy.

\begin{tabular}{|c|c|c|c|}
\hline \multicolumn{4}{|c|}{ Ingredients } \\
\hline Amino Acids & FM & P-POM & P value \\
\hline EAA & & & 0.105 \\
\hline Arginine & $5.74 \pm 0.88$ & $6.84 \pm 0.26$ & 0.962 \\
\hline Histidine & $2.28 \pm 0.31$ & $2.27 \pm 0.08$ & 0.207 \\
\hline Isoleucine & $3.16 \pm 0.50$ & $3.61 \pm 01.8$ & 0.381 \\
\hline Leucine & $5.75 \pm 0.89$ & $6.28 \pm 0.32$ & 0.047 \\
\hline Lysine & $4.67 \pm 0.63^{*}$ & $3.54 \pm 0.29$ & \\
\hline
\end{tabular}




\section{International Journal of Oceanography \& Aquaculture}

\begin{tabular}{|c|c|c|c|}
\hline Methionine & $4.11 \pm 0.69^{*}$ & $2.56 \pm 0.04$ & 0.018 \\
\hline Phenylalanine & $3.22 \pm 0.51$ & $4.77 \pm 0.07^{*}$ & 0.031 \\
\hline Threonine & $3.37 \pm 0.52$ & $4.50 \pm 0.15^{*}$ & 0.025 \\
\hline Valine & $5.21 \pm 0.80$ & $4.09 \pm 0.23$ & 0.081 \\
\hline NEAA & & & 0.011 \\
\hline Alanine & $4.64 \pm 0.64^{*}$ & $2.90 \pm 0.20$ & 0.032 \\
\hline Aspartic Acid & $5.99 \pm 0.75^{*}$ & $4.31 \pm 0.48$ & 0.156 \\
\hline Cystine & $1.78 \pm 0.25$ & $1.52 \pm 0.05$ & 0.025 \\
\hline Glutamic Acid & $9.46 \pm 1.24^{*}$ & $6.78 \pm 0.47$ & 0.226 \\
\hline Glycine & $4.98 \pm 0.77$ & $4.32 \pm 0.19$ & 0.198 \\
\hline Proline & $3.17 \pm 0.46$ & $3.63 \pm 0.24$ & 0.083 \\
\hline Serine & $3.12 \pm 0.45$ & $3.77 \pm 0.18$ & 0.028 \\
\hline Tyrosine & $2.91 \pm 0.48$ & $3.87 \pm 0.13^{*}$ & \\
\hline
\end{tabular}

Table 2: Amino acid composition (\% g sample) of ingredients used for experimental diets.

Tryptophan is not determine

All values are mean $\pm S D$, obtained from three replicates. Values in the same row with ${ }^{*}$ are significantly different $(\mathrm{P}<$ 0.05).

\section{Fish Husbandry and Experimental Conditions}

Snakehead, C. striata [18] fingerlings were obtained from Aquatic Research Complex, Universiti Sains Malaysia. 15 fish (mean initial body weight $13.23 \pm 0.06 \mathrm{~g}$ ) were distributed and reared in 15 black fiber glass tanks $(500 \mathrm{~L})$ outdoors. All tanks were covered tightly to prevent the fish from jumping out from the experimental tanks, continuous aeration was provided to each tank and $50 \%$ water was changed every two days manually. Water quality parameters (temperature, $\mathrm{pH}$ and dissolved oxygen) ranged between $26^{\circ} \mathrm{C}$ to $28^{\circ} \mathrm{C}, 6.10-6.70$ and 4.51-6.44 $\mathrm{mgL}^{-1}$. Fish were hand fed their respective experimental diets twice daily at 9.00 and 17.00 until apparent satiation for 12 weeks. Each experimental diet was assigned to triplicate groups of fish.

\section{Sampling Procedure}

Fish were individually weighed at the beginning and upon completion of feeding trial. Bulk-weighing was done every fortnightly during the feeding trial to monitor the feed consumption and growth performance. In the beginning of the feeding trial, ten fish were sacrificed to determine the muscle proximate composition. At the end of the experiment, the fish were randomly chosen for determination of body indices, proximate muscle composition and digestive enzyme activities. The initial and final experimental fish muscle were taken and kept in $-80^{\circ} \mathrm{C}$ until analysed. The fish muscle were freeze dried (Labconco model Freezone 2.5, Labconco Corporation, Kansas City, England) and ground prior to the analysis.

\section{Analytical and Statistical Analysis}

The effects of the experimental diets on growth were determined by the calculation of growth, nutrient utilization and body indices. These parameters were calculated based on the following formulae:

Specific Growth Rate (SGR) $=100 \times[(\operatorname{lnWt}-\operatorname{lnWi}) / \mathrm{T}]$

Survival $=$ final no fish $/$ initial no fish $\times 100$

Feed Conversion Ratio (FCR) = total feed intake/ total weight gain

Protein Efficiency Ratio (PER) = weight gain/total protein intake

Hepatosomatic index (HSI \%) $=100 \times$ (liver weight $/$ body weight)

Viscerosomatic Index (VSI \%) $=100 \mathrm{x}$ (viscera weight/body weight)

Apparent Digestibility= 100- $100\left[\left(\% \mathrm{Cr}^{2} \mathrm{O}^{3}\right.\right.$ diet $/ \% \mathrm{Cr}^{2} \mathrm{O}^{3}$ faeces) x (\% nutrient faeces / \% nutrient diet)]

Where Wt refers to mean final body weight while Wi is the mean initial body weight, $\mathrm{T}$ is the feeding trial period in days. 


\section{International Journal of Oceanography \& Aquaculture}

\section{Digestive Enzyme Activities}

Six experimental fish were sampled and immediately dissected to collect the intestines. The samples were cleaned and weighed, then homogenized in ice cold distilled water at a of ratio $1 \mathrm{~g}$ tissue to $9 \mathrm{ml}$ using a handheld glass homogenizer. The homogenates were centrifuged at $4^{\circ} \mathrm{C}$ at $30,000 \mathrm{~g}$ for 30 minutes. The supernatant was collected and stored in $-80^{\circ} \mathrm{C}$ for further analysis. The total protein content in the samples were analysed according to Bradford method by using bovine serum albumin as the standard [19]. The protease activity was analysed by using casein-hydrolysis method by Walter [20] and L-tyrosine was used as a standard. One unit of total proteolytic enzyme activity was defined as the quantity of enzyme needed to catalyse the formation of $1 \mu \mathrm{g}$ of tyrosine per 1 minute. The amylase activity was determined by the starch hydrolysis method proposed by Worthington [21] and maltose is used as a standard to determine the specific amylase activity of the sample. The amylase specific activity was defined as the micromole of maltose released per min per mg protein and the lipase activity was determined according to Bier with some modification [22].

\section{Diets Digestibility Analysis}

The digestibility of the experimental diets conducted separately by using aquaria in order to avoid disturbance. Twenty fish were stocked in the aquaria in triplicate groups. The fish were fed similarly with the growth study until satiation twice a day. The fish were acclimated to experimental diets for at least one month before the faecal collection. The tanks were cleaned and uneaten feed were removed before the faeces were collected by siphoning method 4 hours after feeding. The faeces collected were stored in $-20^{\circ} \mathrm{C}$ before analysed. The chromic oxide content of the experimental diets and faeces collected were analysed to determine the nutrient digestibility for each treatments according to method proposed by Furukawa \& Tsukahara [23].

\section{Statistical Analysis}

The ingredients amino acid data was calculated by using Independent Sample T-Test by Levene's Test for Equality of Variances and the rest of the data were calculated by one way analysis of variance (ANOVA) and Duncan's Multiple Range Test was used to detect the significant differences $(\mathrm{P}<0.05)$. The statistical analysis was performed using SPSS Statistical Analysis Software Program for Windows, Version 22.

\section{Results}

\section{Amino Acid Composition of Ingredients}

The amino acid composition of fish meal (FM) and processed poultry offal meal (P-POM) is presented in Table 2. The amino acid profile of P-POM used in this study is comparable to the amino acid profile found in fish meal. Results of the t-test analysis showed that with the exception of lysine and methionine which were higher in fish meal, amino acids such as phenylalanine and threonine were higher in P-POM compared to fish meal. Other essential amino acid is similar between the two feed ingredients.

\section{Growth Performance and Feed Utilization}

The growth data after the twelve-week feeding trial is presented in Table 3. Except for the diet containing 100\% protein from P-POM, replacing FM protein from $25-75 \%$ improved significantly all growth parameters monitored compared to the control diet containing 100\% FM protein. SGR values for the $25-75 \%$ replacement levels did not differ significantly and ranged from $1.33 \pm 0.02$ to $1.42 \pm 0.003$. A similar trend was observed for nutrient utilization (FCR and PER) while replacing fish meal protein with P-POM protein did not affect survival and was above 90 percent for all treatments.

\begin{tabular}{|c|c|c|c|c|c|}
\hline \multirow{2}{*}{ Parameters } & \multicolumn{5}{|c|}{ Experimental Diets } \\
\cline { 2 - 6 } & D1 & D2 & D3 & D4 & D5 \\
\hline Initial weight (g/fish) & $13.26 \pm 0.05^{\mathrm{a}}$ & $13.25 \pm 0.02^{\mathrm{a}}$ & $13.21 \pm 0.04^{\mathrm{a}}$ & $13.21 \pm 0.08^{\mathrm{a}}$ & $13.22 \pm 0.08^{\mathrm{a}}$ \\
\hline Final weight (g/fish) & $38.00 \pm 1.93^{\mathrm{a}}$ & $40.98 \pm 1.08^{\mathrm{b}}$ & $40.27 \pm 0.52^{\mathrm{ab}}$ & $43.19 \pm 0.18^{\mathrm{c}}$ & $38.71 \pm 2.54^{\mathrm{ab}}$ \\
\hline Weight gain & $24.74 \pm 1.95^{\mathrm{a}}$ & $27.74 \pm 1.06^{\mathrm{b}}$ & $27.06 \pm 0.55^{\mathrm{ab}}$ & $30.19 \pm 0.10^{\mathrm{c}}$ & $25.49 \pm 1.51^{\mathrm{ab}}$ \\
\hline Survival rate (\%) & $95.56 \pm 1.50^{\mathrm{a}}$ & $93.33 \pm 0.70^{\mathrm{a}}$ & $93.33 \pm 1.20^{\mathrm{a}}$ & $93.33 \pm 1.20^{\mathrm{a}}$ & $95.56 \pm 1.50^{\mathrm{a}}$ \\
\hline
\end{tabular}




\section{International Journal of Oceanography \& Aquaculture}

\begin{tabular}{|c|c|c|c|c|c|}
\hline Feed intake (g/fish) & $32.19 \pm 2.28^{\mathrm{a}}$ & $34.91 \pm 0.63^{\mathrm{b}}$ & $34.51 \pm 1.24^{\mathrm{ab}}$ & $36.96 \pm 0.54^{\mathrm{b}}$ & $31.43 \pm 1.38^{\mathrm{a}}$ \\
\hline SGR $^{2}$ & $1.25 \pm 0.06^{\mathrm{a}}$ & $1.34 \pm 0.03^{\mathrm{bc}}$ & $1.33 \pm 0.02^{\mathrm{ab}}$ & $1.42 \pm 0.003^{\mathrm{c}}$ & $1.28 \pm 0.05^{\mathrm{ab}}$ \\
\hline FCR $^{1}$ & $1.33 \pm 0.05^{\mathrm{ab}}$ & $1.30 \pm 0.03^{\mathrm{ab}}$ & $1.32 \pm 0.05^{\mathrm{ab}}$ & $1.26 \pm 0.02^{\mathrm{a}}$ & $1.39 \pm 0.06^{\mathrm{b}}$ \\
\hline PER $^{3}$ & $1.87 \pm 0.07^{\mathrm{ab}}$ & $1.92 \pm 0.05^{\mathrm{ab}}$ & $1.89 \pm 0.07^{\mathrm{ab}}$ & $1.98 \pm 0.03^{\mathrm{b}}$ & $1.81 \pm 0.08^{\mathrm{a}}$ \\
\hline
\end{tabular}

Table 3: Growth performance and feed utilization of snakehead, C. striata juvenile fed with experimental diets for 12 weeks.

All values are mean \pm SD, obtained from three replicates. Values in the same row with different superscript letters are significantly different $(\mathrm{P}<0.05)$

${ }^{1} \mathrm{SGR}$ (Specific growth rate) $=100 \times$ (ln final mean weight $-\ln$ initial mean weight)

${ }^{2}$ FCR (Feed conversion ratio) $=$ feed intake/ weight gain

3PER (Protein efficiency ratio) $=$ weight gain $/$ protein intake

\section{Muscle Proximate Composition}

The muscle proximate composition and body indices are shown in Table 4. Muscle protein was significantly highest in the control diet $(824.30 \pm 0.15)$ and in fish fed the diets containing $25 \%$ replacement level $(825.13 \pm 0.12)$ and significantly lowest when $100 \%$ FM protein $(810.82 \pm 0.09)$ was replaced. There is an increasing trend in the crude lipid content of the fish muscle as inclusion levels of P-POM increased whereby
$100 \%$ replacement resulted in highest muscle lipid content $(79.41 \pm 0.80)$. The ash content of the fish muscle composition decreased with the increasing inclusion of PPOM. The HSI values significantly increased from $50 \%$ replacement to $75 \%$ replacement as compared to the $0 \%$, $25 \%$ and $100 \%$ P-POM replacement. However, the VSI values were not affected with increasing inclusion levels of P-POM in the diets of snakehead juveniles.

\begin{tabular}{|c|c|c|c|c|c|}
\hline \multicolumn{7}{|c|}{ Experimental Diets } \\
\hline \multicolumn{7}{|c|}{ D1 } & D2 & D3 & D4 & D5 \\
\hline \multicolumn{7}{|c|}{ Muscle proximate composition } \\
\hline Moisture & $677.50 \pm 0.70^{\mathrm{a}}$ & $722.51 \pm 3.30^{\mathrm{ab}}$ & $685.00 \pm 3.60^{\mathrm{a}}$ & $727.60 \pm 5.70^{\mathrm{ab}}$ & $751.62 \pm 7.90^{\mathrm{c}}$ \\
\hline Crude protein & $824.30 \pm 1.50^{\mathrm{cd}}$ & $825.13 \pm 1.20^{\mathrm{d}}$ & $819.60 \pm 0.60^{\mathrm{b}}$ & $822.83 \pm 1.20^{\mathrm{c}}$ & $810.82 \pm 0.90^{\mathrm{a}}$ \\
\hline Crude lipid & $59.62 \pm 7.40^{\mathrm{a}}$ & $60.80 \pm 6.40^{\mathrm{a}}$ & $67.50 \pm 2.90^{\mathrm{a}}$ & $68.70 \pm 3.50^{\mathrm{ab}}$ & $79.41 \pm 8.00^{\mathrm{b}}$ \\
\hline Crude ash & $74.42 \pm 4.00^{\mathrm{b}}$ & $66.82 \pm 9.20^{\mathrm{ab}}$ & $58.70 \pm 3.30^{\mathrm{a}}$ & $56.90 \pm 8.30^{\mathrm{a}}$ & $55.11 \pm 5.70^{\mathrm{a}}$ \\
\hline \multicolumn{7}{|c|}{ Body indices } & & $1.30 \pm 0.10^{\mathrm{a}}$ \\
\hline HSI $(\%)^{1}$ & $1.27 \pm 0.06^{\mathrm{a}}$ & $1.37 \pm 0.15^{\mathrm{a}}$ & $1.67 \pm 0.12^{\mathrm{b}}$ & $1.77 \pm 0.06^{\mathrm{b}}$ & $4.50 \pm 0.10^{\mathrm{ab}}$ \\
\hline VSI $(\%)^{2}$ & $4.43 \pm 0.15^{\mathrm{a}}$ & $4.50 \pm 0.10^{\mathrm{ab}}$ & $4.67 \pm 0.06^{\mathrm{b}}$ & $4.73 \pm 0.06^{\mathrm{b}}$ & $4.5196 \mathrm{fed}$ \\
\hline
\end{tabular}

Table 4: Muscle proximate composition ( $\mathrm{gkg}^{-1}$ ) and body indices of snakehead, C. striata fed with experimental diets for 12 weeks.

All values are mean $\pm \mathrm{SD}$, obtained from three replicates. Values in the same row with different superscript letters are significantly different $(\mathrm{P}<0.05)$

${ }^{1}$ HSI $($ Hepatosomatic index $)=100 \times$ (liver weight/body weight)

2VSI (Viserasomatic index) $=100 \times$ (visceral weight/ body weight) 


\section{Muscle Amino Acid Composition}

The essential and non-essential amino acid compositions of fish muscle are presented in Figures 1 and 2. Lysine and cysteine was significantly higher $(\mathrm{P}<0.05)$ in fish fed $0 \%$ inclusion level of $\mathrm{P}-\mathrm{POM}$ compared to the other treatments. The aspartic acid and glutamine increased with increasing inclusion level of PPOM and was significantly highest in fish fed 75\% P-POM inclusion level. In addition, tyrosine was significantly higher in fish fed 25\% P-POM inclusion level compared to the other treatments. As a comparison to the initial muscle, the leucine in the muscle after 12 weeks feeding trial increased significantly in all treatments with increasing P-POM inclusion levels. However, there was no particular trend on the other essential and non-essential amino acid of fish muscle fed with the experimental diets.
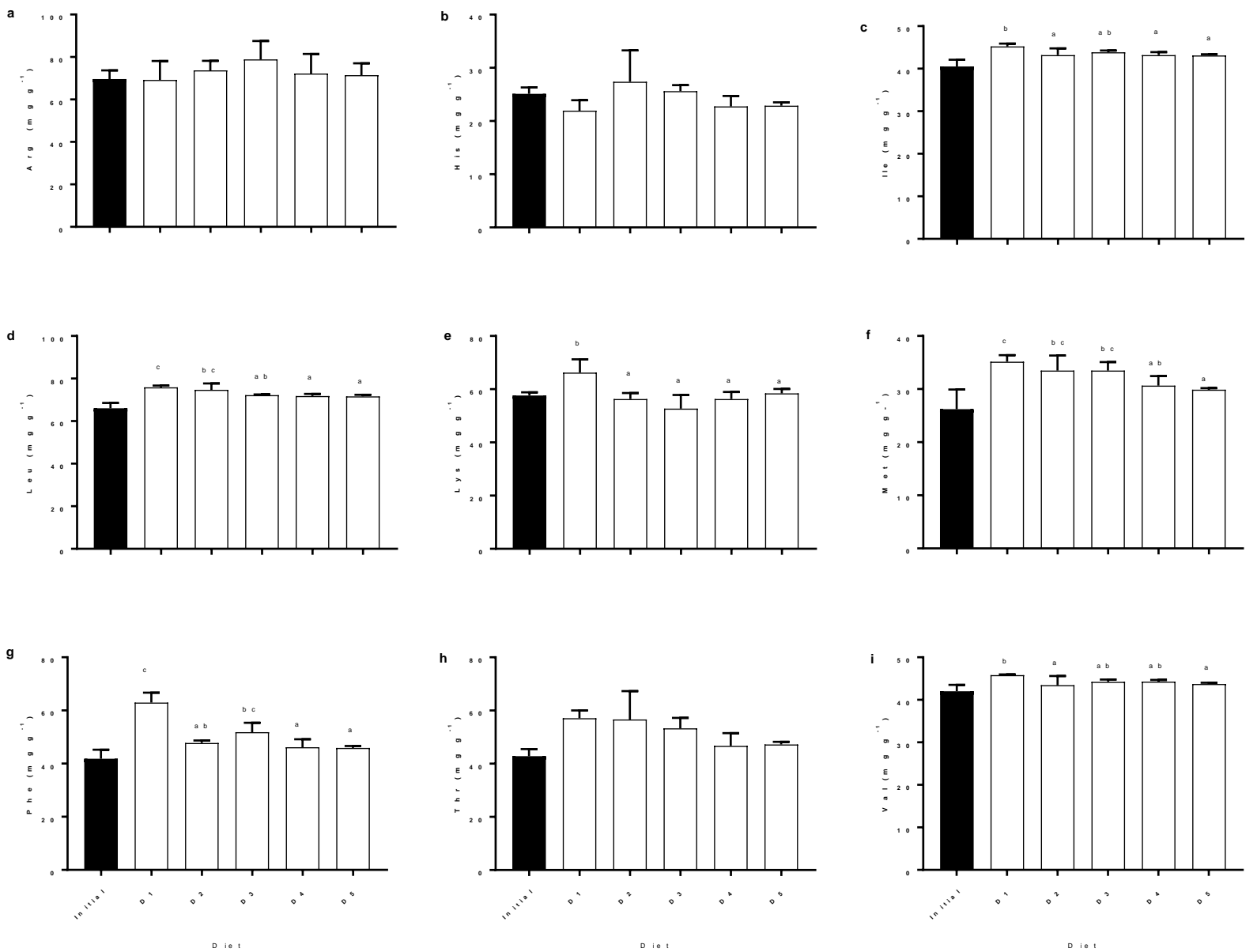

Figure 1: Essential amino acid composition of muscle tissue $\left(\mathrm{mgg}^{-1}\right)$ of snakehead fed different P-POM inclusion levels; a) arginine b) histidine c) isoleucine d) leucine e) lysine f) methionine g) phenylalanine h) threonine i) valine.All values are mean $\pm \mathrm{SD}$, obtained from three replicates. Values with different superscript letters are significantly different $(\mathrm{P}<0.05)$. 

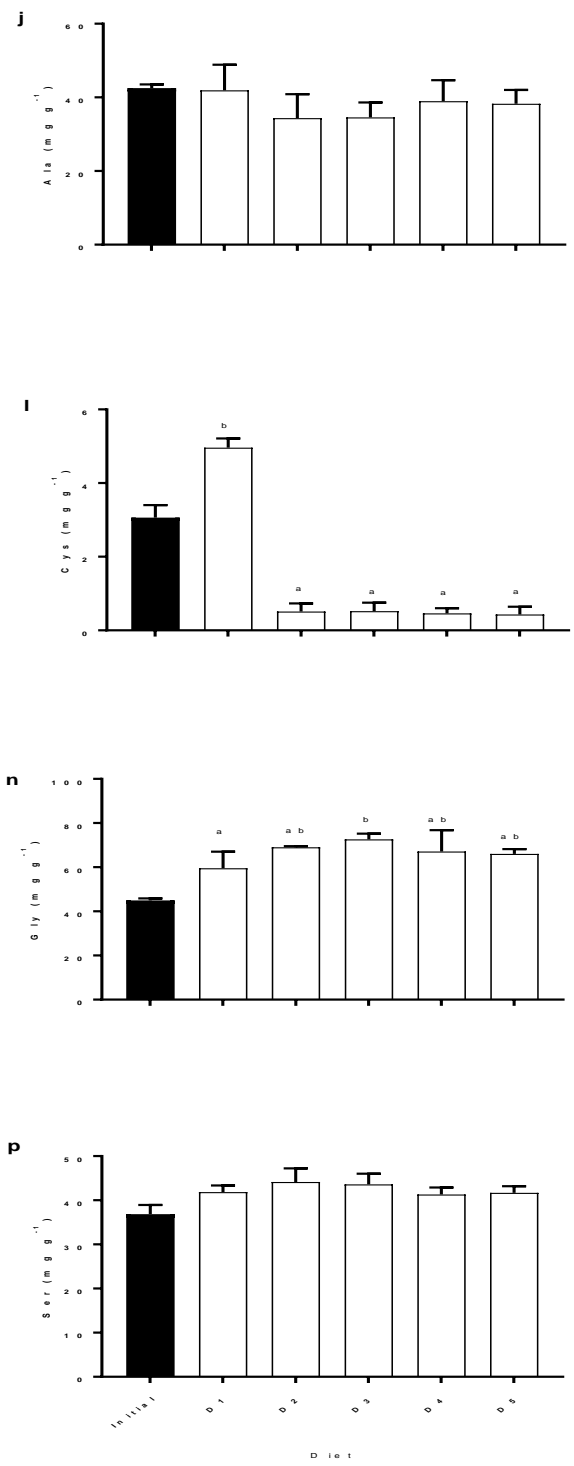

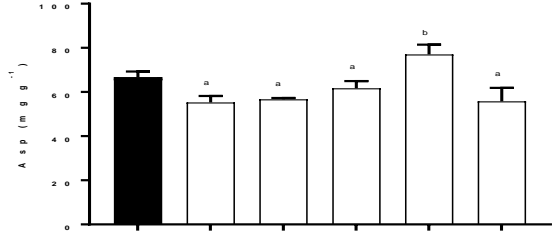

m
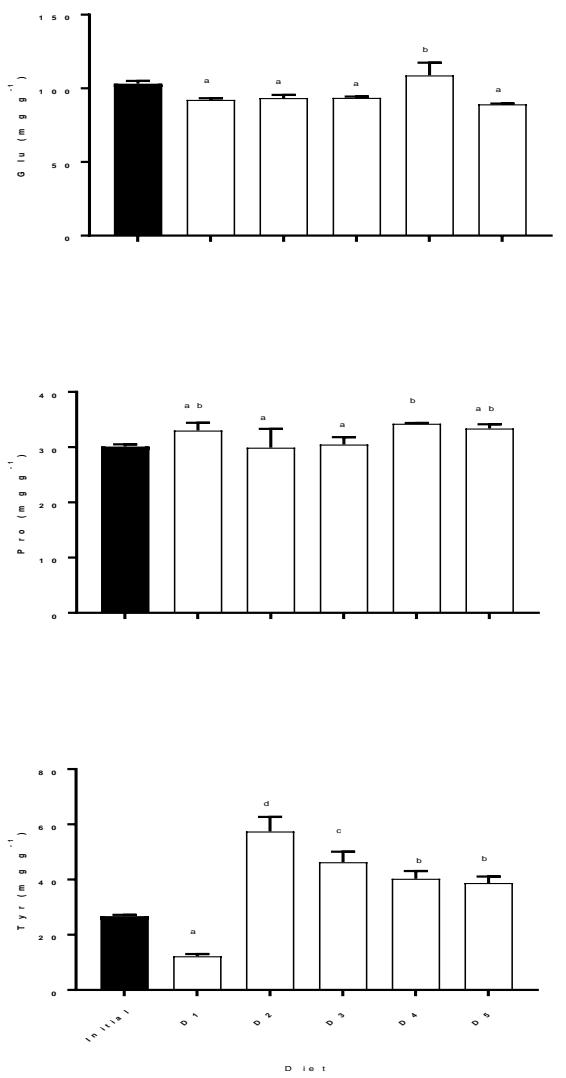

Figure 2: Non-essential amino acid composition of muscle tissue (mgg- ${ }^{1}$ ) of snakehead feddifferent P-POM inclusion levels; j) alanine k) aspartic acid l) cysteine $\mathrm{m}$ ) glutamic acid $\mathrm{n}$ ) glycine o) proline $\mathrm{p}$ ) serine $\mathrm{q}$ ) tyrosine. All values are mean $\pm \mathrm{SD}$, obtained from three replicates. Values with different superscript letters are significantly different $(\mathrm{P}<$ 0.05).

\section{Digestive Enzyme Activities}

The specific protease, lipase and amylase enzyme activity data are presented in Table 5. Significantly highest protease activities was observed in fish fed with $75 \%$ diets $(2.47 \pm 0.32)$ compared to other treatments. Lipase activity was significantly lowest in the control and
$100 \%$ replacement diet but almost doubled in the fish fed $25 \%$ to $75 \%$ P-POM replacement levels. No significant differences $(\mathrm{P}>0.05)$ were observed in the amylase activities. The highest amylase activity was observed in fish fed $75 \%(1.70 \pm 0.22)$ and the lowest was recorded in $100 \%$ inclusion of P-POM. 


\section{International Journal of Oceanography \& Aquaculture}

\section{Apparent Digestibility Coefficients}

Apparent protein digestibility (APD) did not differ significantly between all diets except the diets containing $100 \%$ P-POM replacement. However, the apparent dry matter increase with the increasing inclusion of P-POM and the ADM for the 75\% P-POM replacement were significantly higher $(\mathrm{P}<0.05)$ compared to fish fed the other treatments.

\section{Discussion}

The replacement of fish meal (FM) with poultry offal meal (POM) has been investigated for several fish species such as European sea bass and gilthead sea bream [2426], humpback grouper [27], black sea turbot [28], walking catfish [29] and tiger grouper [30] but little information is available for snakehead, Channa striata juveniles. Generally, the results of this study suggest that the prepared or processed poultry offal meal (P-POM) could be used to replace FM up to $75 \%$ of FM protein with no adverse effects on growth performance and even up to $100 \%$ without compromising fish survival. This is in contrast with a previous study using commercial POM under similar culture conditions [31].

All the growth parameters and nutrient utilization improved significantly up to $75 \%$ P-POM protein inclusion levels indicating that snakehead juveniles can utilize high level of P-POM in their diets. This observation may be due to the quality of the P-POM which contained similar protein and amino acid profiles to the FM used in this study (Table 2). With the exception of lysine and methionine which were lower in P-POM, other essential amino acids such as alanine, aspartic acid, glutamic acid and tyrosine were higher while phenylalanine and threonine were similar to that of FM. Furthermore, dietary intake of P-POM did not affect muscle proximate composition which was expected due to the similar protein and lipid levels. This observation is in agreement with previous studies on red sea bream [26], humpback grouper [15] and tiger grouper [30].

In addition, improved palatability and nutrient digestibility of P-POM containing diets compared to the control diet may have contributed to the observed increase in growth performance and feed utilization in snakehead. The significant increase in feed intake of fish fed with the P-POM up to 75\% inclusion levels (Table 3 ) indicates high palatability of the diets containing P-POM. Generally, palatability is influenced by the nutrients and toxin content of the diet, the nutritional needs of the fish and also the fish's past experience with the feed [32]. The fact that the P-POM used had approximately $73 \%$ protein and an amino acid profile which had high levels of alanine, glycine, arginine and proline probably contributed to the increased acceptability, palatability and digestibility of the P-POM diets by the snakehead juveniles [33,34]. Enhanced growth was further supported by the significant improvement in apparent dry matter digestibility as the P-POM level increased from $25 \%$ to $75 \%$. However, growth was compromised beyond $75 \%$ because of lower palatability evident by the lower feed intake and a slower gut transit rate caused by the reduced ash content in the 100\% P-POM diet [35]. Body indices were generally similar with significant increases in HSI when fish were fed $50 \%$ to $100 \%$ P-POM compared to fish fed diet $0 \%$ and $25 \%$ P-POM. Since no significant difference was detected in the muscle lipid (Table 4), it is likely that any excess lipid from the feed was be deposited in the liver. Similar results were also observed in a study done with Korean rockfish that showed increasing HSI value with increasing feeding rate and feed intake [36].

The protease enzyme activities in response to the ingestion of the experimental diets further supports the growth trends in this study (Tables $5 \&$ 6). Gut protease activities of snakehead a juvenile increased with increasing inclusion levels of P-POM and was significantly highest in fish fed the 75\% P-POM diet. The similar lipase activities observed were expected as the level and ratio of the two different lipids (fish oil and poultry fat) used were similar in all the test diets and although there were differences in the carbohydrate content of the diets, amylase activities were unaffected probably because of the low ability of the carnivorous snakehead to utilize and digest carbohydrate.

\begin{tabular}{|c|c|c|c|}
\hline $\begin{array}{c}\text { Experimental } \\
\text { diets }\end{array}$ & $\begin{array}{c}\text { Protease } \\
\text { activity (Umg-1 } \\
\text { protein) }\end{array}$ & $\begin{array}{c}\text { Lipase } \\
\text { Activity } \\
\text { (Umg- } \\
\text { 1protein) }^{\text {Activity }}\end{array}$ & $\begin{array}{c}\text { Amylase } \\
\text { Activity } \\
\text { (Umg-1 } \\
\text { protein) }\end{array}$ \\
\hline D1 & $1.02 \pm 0.05^{\mathrm{a}}$ & $5.34 \pm 0.26^{\mathrm{a}}$ & $1.50 \pm 0.32^{\mathrm{a}}$ \\
\hline D2 & $1.41 \pm 0.31^{\mathrm{a}}$ & $10.41 \pm 0.65^{\mathrm{b}}$ & $1.54 \pm 0.30^{\mathrm{a}}$ \\
\hline D3 & $1.42 \pm 0.36^{\mathrm{a}}$ & $10.72 \pm 0.94^{\mathrm{b}}$ & $1.53 \pm 0.24^{\mathrm{a}}$ \\
\hline D4 & $2.47 \pm 0.32^{\mathrm{b}}$ & $11.40 \pm 0.35^{\mathrm{b}}$ & $1.70 \pm 0.22^{\mathrm{a}}$ \\
\hline D5 & $1.03 \pm 0.09^{\mathrm{a}}$ & $6.24 \pm 0.16^{\mathrm{a}}$ & $1.47 \pm 0.12^{\mathrm{a}}$ \\
\hline
\end{tabular}

Table 5: Protease, Lipase and Amylase enzyme activity of snakehead juvenile, C. striata fed with different inclusion levels of P-POM.

All values are mean $\pm S D$, obtained from three replicates. Values with different superscript letters are significantly different $(\mathrm{P}<0.05)$. 


\section{International Journal of Oceanography \& Aquaculture}

\begin{tabular}{|c|c|c|}
\hline \multirow{2}{*}{ Experimental diets } & \multicolumn{2}{|c|}{ Apparent Digestibility (\%) } \\
\cline { 2 - 3 } & APD $^{\mathbf{1}}$ & ADM $^{\mathbf{2}}$ \\
\hline D1 & $79.82 \pm 0.71^{\mathrm{b}}$ & $73.74 \pm 0.24^{\mathrm{a}}$ \\
\hline D2 & $79.48 \pm 0.53^{\mathrm{b}}$ & $73.74 \pm 0.24^{\mathrm{a}}$ \\
\hline D3 & $79.58 \pm 0.65^{\mathrm{b}}$ & $74.71 \pm 0.62^{\mathrm{b}}$ \\
\hline D4 & $79.70 \pm 0.30^{\mathrm{b}}$ & $75.43 \pm 0.25^{\mathrm{c}}$ \\
\hline D5 & $77.20 \pm 0.49^{\mathrm{a}}$ & $73.13 \pm 0.25^{\mathrm{a}}$ \\
\hline
\end{tabular}

Table 6: Apparent digestibility (\%) dry matter and protein of juvenile snakehead, C. striata fed with inclusion level of poultry offal meal after 12 weeks.

All values are mean \pm SD obtained from three replicates

${ }^{1}$ Apparent protein digestibility

${ }^{2}$ Apparent dry matter

A comparison of the final and initial muscle essential amino acid profile showed that the muscle leucine content increased significantly in all treatments compared to the initial muscle. Leucine is a branched chain amino acid which is essential for fish and it works together with other essential amino acids namely valine and isoleucine to protect the fish muscle and is also important in the wound healing processes [37]. Based on this observation, as snakehead is recommended for those recovering from surgery, it can be suggested that replacing FM with P-POM can lead to an increase in leucine level in the muscle contributing further towards the medicinal benefits of this fish. Although non-essential amino acids (NEAA) are synthesized de novo in the body, some of the NEAA play an important roles in gene expression regulation, cell signalling, nutrient transport and cell metabolism, antioxidative responses and immune response [38]. However, in this study the muscle cysteine content decreased significantly with increasing replacement level of P-POM in the diets of snakehead. This is might due to the suppression of cysteine cause by the intake of P-POM, so further study should be conducted to investigate the cysteine suppression caused by the intake of this particular alternative protein source in snakehead.

\section{Conclusion}

In conclusion, based on the growth performance and muscle quality content, the poultry offal processed according to the method described in this study can be used as an alternative to fish meal up to $75 \%$ inclusion level in the diets of snakehead juvenile.

\section{Acknowledgement}

The author would like to thank all the staff in School of Biological Sciences, Universiti Sains Malaysia for their help and assistance throughout this project.

\section{References}

1. Mohsin AKM, Ambak MA (1983) Freshwater Fishes of Peninsular Malaysia, Universiti Pertanian Malaysia Press: Kuala Lumpur, pp: 284.

2. Hossain MK, Latifa GA, Rahman MM (2008) Observations on induced breeding of snakehead murrel, Channa striatus (Bloch, 1793). International Journal of Sustainable Crop Production 3: 65-68.

3. Rahman MA, Awal S (2016) Development of Captive Breeding, Seed Production and Culture Techniques of Snakehead Fish for Species Conservation and Sustainable Aquaculture. International Journal of Advances in Agricultural \& Environmental Engineering 3: 117-120.

4. Ng PKL, Lim KKP (1990) Snakeheads (Pisces: Channidae): Natural history, biology and economic importance. In Chou LM, Ng KLP (Eds.), Essays in Zoology: Papers Commemorating the $40^{\text {th }}$ Anniversary of the Department of Zoology, National University of Singapore. Department of Zoology, National University of Singapore, Singapore, pp: 127152.

5. FAO (2016) The State of World Fisheries and Aquaculture.

6. Rahman MM, Choi J, Lee SM (2013) Influences of dietary distillers dried grain level on growth performance, body composition and biochemical parameters of juvenile olive flounder (Paralichthys olivaceus). Aquaculture Research 1-10.

7. Kristofersson D, Anderson JL (2006) Is there a relationship between fisheries and farming? Interdependence of fisheries, animal production and aquaculture. Marine Policy 30: 721-725.

8. Mohanta KN, Subramanian S, Korikanthimath VS (2013) Evaluation of Different Animal Protein Sources in Formulating the Diets for Blue Gourami, Trichogaster Trichopterus Fingerlings. Journal Aquaculture Research Development 4: 164. 


\section{International Journal of Oceanography \& Aquaculture}

9. Tidwell JH, Coyle SD, Bright LA, Yasharian D (2005) Evaluation of plant and animal source proteins for replacement of fish meal in practical diets for the largemouth bass Micropterus salmoides. Journal of World of Aquaculture Society 36(4): 454-463.

10. Hussain J, Khan FU, Ullah R, Muhammad Z, Rehman $\mathrm{NU}$, et al. (2011) Nutrient evaluation and elemental analysis of four selected medicinal plants of Khyber Pakhtoon Khwa, Pakistan. Pak J Bot 43(1): 427-434.

11. FAO (2015) The State of World Fisheries and Aquaculture.

12. Gerber P, Opio C, Steinfeld H (2005) Poultry production and the environment - A review. 1-27.

13. FAO (2011) The State of World Fisheries and Aquaculture. FAO Fisheries and Aquaculture Department Food and Agriculture Organization of the United Nation, Rome.

14. Watson H (2006) Poultry meal vs poultry by product meal. Published in Dogs in Canada Magazine.

15. Shapawi R, Ng WK, Mustafa S (2007) Replacement of fish meal with poultry by-product meal in diets formulated for the humpback grouper, Cromileptes altivelis. Aquaculture 273: 118-126.

16. Ismail S, Salleh M, Ramezani E (2013) Performance of commercial poultry offal meal as fishmeal replacement in the diet of juvenile Malaysian mahseer, Tor tramboides. Journal of Animal Veterinary Advance 8(2): 284-292.

17. Association of Official Analytical Chemists (1997) Animal feeds. Cunniff PA (Eds.), Official Methods of AOAC International $16^{\text {th }}$ (Edn.), AOAC, Arlington, Virginia, USA, 1: 1-3.

18. Bloch ME (1973) Naturgeschichte der Auslandischen Fische 8: 144

19. Bradford M (1976) A rapid and sensitive method for the quantification of microgram quantities of protein utilizing the principle of protein-dye binding. Analytical Biochemistry 72(1-2): 248-254.

20. Walter HE (1984) Proteinases: Methods with haemoglobin, casein and azocoll as substrates. In: ergmeyer HU(Edn.), Methods of Enzyaic Analysis, Vol (5), Verlag Chemie, Weinheim, Germany, pp: 270-277.
21. Worthington TM (1982) Enzymes and Related Biochemical. Biochemical Products Division, Worthington Diagnostic System, Freehold, NJ, USA.

22. Bier M (1995) Lipases. Methods in Enzymology I. Academy Press, New York, pp: 627-642.

23. Furukawa A, Tsukahara H (1966) On the acid digestion method for the determination of chromic oxide as an index substance in the study of digestibility of fish feed. Bulletin Japanese Society Science Fish 32: 502-506.

24. Alexis MN (1997) Fish meal and fish oil replacers in Mediterranean marine fish diets. Tacon A Barsureo B (Eds.), Feeding tomorrow's fish Zaragoza, Spain, pp: 183-204.

25. Nengas I, AlexisMN, Davies SJ (1999) High inclusion levels of poultry meals and related by products in diets for gilthead seabream, Sparus aurata L. Aquaculture 179: 13-23.

26. Takagi ST, Hosokawa H, Shimeno S, Ukawa M (2000) Utilization of poultry by-product meal in a diet for red sea bream, Pagrus major. Nippon Suisan Gakkaishi 66: 428-438.

27. Usman Rachmansyah, Palinggi NN, Ahmad T (2007) Utilization of Local Feed Ingredients in Tiger Grouper Grow Out Moist Diets. Asia Pacific Marine Finfish Aquaculture Network Magazine 33-41.

28. Yigit M, Erdem M, Koshio S, Ergun S, Turker A, et al. (2006) Substituting fish meal with poultry by-product meal in diets for black Sea turbot Psetta maeotica. Aquaculture Nutrition 12: 340-347.

29. Giri SS, Sahoo SK, Mohanty SN (2010) Replacement of by-catch fishmeal with dried chicken viscera meal in extruded feeds: effect on growth, nutrient utilisation and carcass composition of catfish, Clarias batrachus (Linn.) fingerlings. Aquaculture International 18: 539544.

30. Gunben EM, Senoo S, Yong A, Shapawi R (2014) High Potential of Poultry by-product Meal as a Main rotein Source in the Formulated Feeds for a Commonly Cultured Grouper in Malaysia (Ephinephelus fuscoguttatus). Sains Malaysiana. 43: 399-405.

31. Abdul Halim HH, Aliyu-Paiko M, Hashim R (2014) Partial replacement of fish meal with poultry by 


\section{International Journal of Oceanography \& Aquaculture}

product meal in diets for snakehead, Channa sriata (Bloch, 1793) fingerlings. Journal of World Aquaculture Society 45(2): 233-241.

32. Tankitti C (2014) Feed palatability and the alternative protein sources in shrimp feed. Journal of Science Technology 36(1): 51-55.

33. Marui T, Caprio J (1992) Teleost gustation. In. Fish Chemoreception, Hara TJ (Edn.), Chapman \& Hall, London, pp: 171-198.

34. Hara TJ (1994) Olfaction and gustation: an overview. Acta Physiologica Scandinavian 152: 207-217.

35. Yang Y, Xie S, Cui Y, Lei W, Zhu X, et al. ( 2004) Effect of replacement of dietary fish meal by meat and bone meal and poultry by-product meal on growth and feed utilization of gibel carp, Carassius auratus gibelio. Aquaculture Nutrition 10: 289-294.

36. Mizanur RM, Yun HH, Moniruzzaman M, Ferreira F, Kim KW, et al. (2014b) Effects of feeding rate and water temperature on growth and body composition of Juvenile Korean Rockfish, Sebastes schlegeli (Hilgendorf 1880). Asian-Australas J Anim Sci 27: 690-699.

37. Campbell MG (2009) The Nine Essential Amino Acids. http://campbellmgold.com

38. Wu G (2010) Functional amino acids in growth, reproduction, and health. Adv Nutr 1(1): 31-37. 